\title{
Response of Castor (Ricinus communis L.) To Varying Weather Variables and Crop Geometry with Levels of Nitrogen under Rabi Season
}

\author{
Mukesh Kumar Man*, A.U. Amin, K.M. Choudhary and Annu Devi Gora \\ Department of Agronomy, C.P. College of Agriculture, S.D. Agricultural University, \\ Sardarkrushinagar 385 506, India \\ *Corresponding author:
}

\begin{abstract}
A B S T R A C T
A field experiment was conducted on loamy sand soil during rabi season of 2011-12 and 2012-13 to find out the response of three weather variables $\left(15^{\text {th }}\right.$ September, $30^{\text {th }}$ September and $15^{\text {th }}$ October) and three crop geometry $(150 \mathrm{~cm} \times 60 \mathrm{~cm}, 120 \mathrm{~cm} \times 60 \mathrm{~cm}$ and $90 \mathrm{~cm} \mathrm{x} 60 \mathrm{~cm}$ ) with two levels of nitrogen $\left(80 \mathrm{~kg}\right.$ and $\left.120 \mathrm{~kg} \mathrm{ha}^{-1}\right)$ on growth, yield

\begin{tabular}{|l|}
\hline Ke y w o r d s \\
Castor, \\
$\begin{array}{l}\text { Dates of sowing, } \\
\text { Crop geometry, } \\
\text { Nitrogen }\end{array}$ \\
\hline Article Info \\
\hline $\begin{array}{l}\text { Accepted: } \\
\text { 25 April 2017 } \\
\text { Available Online: } \\
\text { 10 May } 2017\end{array}$ \\
\hline
\end{tabular}
attributes and yield of castor (Ricinus communis L.). In general, growth and yield attributes decreased with delay in sowing from $15^{\text {th }}$ September to $30^{\text {th }}$ October. The growth characters viz., plant height, number of branches per plant and numbers of nodes up to primary spike as well as yield attributing parameters viz., length of primary spike, number of capsules per primary spike, number of effective spikes per plant, seed yield per primary spike and per plant as well as seed yield of first and second pickings were significantly higher under early sown crop i.e. $15^{\text {th }}$ September than late sown crop i.e. $15^{\text {th }}$ October. The growth parameters viz., plant height and number of nodes up to primary spikes was significantly higher under crop geometry $90 \mathrm{~cm}$ x $60 \mathrm{~cm}$ than $150 \mathrm{~cm}$ x $60 \mathrm{~cm}$ crop geometry. While, number of branches per plant was the significantly maximum under crop geometry at $150 \mathrm{~cm} \times 60 \mathrm{~cm}$. Significantly the higher values of yield attributes were recorded under crop geometry of $150 \mathrm{~cm}$ x $60 \mathrm{~cm}$ as compared to crop geometry of $90 \mathrm{~cm}$ x $60 \mathrm{~cm}$. Both the wider crop geometry i.e. $150 \mathrm{~cm}$ x $60 \mathrm{~cm}$ and $120 \mathrm{~cm}$ x $60 \mathrm{~cm}$ were at par and recorded significantly higher seed and stalk yields as well as productivity per day than crop geometry of $90 \mathrm{~cm}$ x $60 \mathrm{~cm}$. Fertilizing the castor crop with $120 \mathrm{~kg} \mathrm{~N}^{-1}$ significantly increased growth and yield parameters as well as seed and stalk yields of castor than $80 \mathrm{~kg} \mathrm{~N} \mathrm{ha}^{-1}$. Interaction effect between dates of sowing and crop geometry was significant and $\mathrm{D}_{1} \times \mathrm{XG}_{1}$ i.e. crop sown on $15^{\text {th }}$ September at $150 \mathrm{~cm} \times 60 \mathrm{~cm}$ crop geometry recorded the maximum number of branches per plant, number of effective spikes per plant, seed yield per plant, seed yield of first and second pickings.
\end{abstract}

\section{Introduction}

Castor is an important non-edible oilseed crop grown during the monsoon season mainly for its seed, from which $40-50 \%$ oil is extracted. It does well both under dry land or rainfed farming and limited irrigation due to deep root-system. Its cultivation is becoming popular in north-western part of the country owing to its better performance under stress conditions and higher export potential. Newly developed genotypes of castor are different from the traditional ones in terms of morphology, duration, growth response, and productivity (Kumar et al., 2003; Raghavaiah et al., 2003). They also respond differently to 
different agro-climatic conditions. In northwestern part of the country, some of rainyseason sown castor genotypes continue to produce flowers and fruits till April- May. During this period, these genotypes produce considerable amount of litter in the form of leaves, flowers, pods and twigs resulting in significant contribution to soil organic carbon content and soil organic carbon content related changes in physico-chemical properties of soil. Plant density and $\mathrm{N}$ requirement of genotypes vary substantially with management practices and agro-climatic conditions. Considering these factors, the present study was undertaken to evaluate the performance of 2 genotypes under different inter-row spacing and $\mathrm{N}$ levels in terms of productivity, economics and changes in soil physicochemical properties over the experimental period.

\section{Materials and Methods}

A fixed plot field investigation was conducted at S. D. Agricultural University, Sardarkrushinagar (Gujarat) during the rabi seasons of 2011-12 and 2012-13 on sandyloam soils, having 185, 41.50 and $289 \mathrm{~kg} / \mathrm{ha}$ available $\mathrm{N}, \mathrm{P}$ and $\mathrm{K}$ respectively. The initial soil organic carbon content, $\mathrm{pH}$ and bulk density were $0.19 \%, 7.82$ and $1.31 \mathrm{Mg} / \mathrm{m}^{3}$ respectively. Treatment combinations comprising 3 dates of sowing $\left(15^{\text {th }}\right.$ September, $30^{\text {th }}$ September and $15^{\text {th }}$ October) and three crop geometry $(150 \mathrm{~cm} \times 60 \mathrm{~cm}$, $120 \mathrm{~cm} \times 60 \mathrm{~cm}$ and $90 \mathrm{~cm} \times 60 \mathrm{~cm}$ ) with two levels of nitrogen $\left(80 \mathrm{~kg}\right.$ and $120 \mathrm{~kg} \mathrm{ha}^{-1}$ ) were laid out in a 4 times replicated splitsplit-plot design, where dates of sowing were allotted to main plots, crop geometry in sub plots and $\mathrm{N}$ levels to sub-sub plots. The crop was sown according to dates of sowing. The crop received $25 \mathrm{~kg}$ each of $\mathrm{P} 2 \mathrm{O} 5$ and $20 \mathrm{~kg}$ sulphur at the time of field preparation. As per treatment, half dose of nitrogen was applied as basal dose and remaining quantity of nitrogen was applied as top dressing in two equal splits at 35 and 70 DAS in form of urea. The crop received 2 weedings, at 20 and 40 days after planting, and there was no need of weeding the crop thereafter. Crop received 6 irrigations during each crop season. The crop was harvested by picking of matured spikes at different growth stages. The oil content in seed was determined using nuclear magnetic resonance. Five plants were tagged randomly in the net plot area for sampling in each plot at 50 days and were used for recording growth and yield attributes of the crop under different treatments. Economics such as net returns and benefit: Cost ratios were worked out at the existing market rate. The experiment was conducted on the same site without any change in the layout plan. Bulk density, $\mathrm{pH}$ and soil organic carbon and available $\mathrm{N}$ content of soil were determined at the beginning of experiment and after harvesting of crop. For this purpose, soil samples were drawn from each treatment and analysed for these physico-chemical properties.

\section{Results and Discussion}

\section{Effect of dates of sowing}

It is evident from Table 1.1 that the plant population at 30 DAS and at harvest was not influenced significantly due to different dates of sowing during the course of investigation and in pooled data.

The results presented in Table 1.1 revealed that the effect of dates of sowing on number of branches per plant was significant. Number of branches per plant reduced significantly with each delay in sowing from $15^{\text {th }}$ September to $15^{\text {th }}$ October. Significantly the maximum number of branches per plant of 8.00, 7.52 and 7.76 were recorded when crop was sown on $15^{\text {th }}$ September during 2011-12, 2012-13 and in pooled data also, respectively. 
However, significantly the minimum number of branches per plant of 5.67, 5.37 and 5.52 were observed under late sowing i.e. $15^{\text {th }}$ October during both the years and also in pooled data, respectively. Plants under $15^{\text {th }}$ September got more number of branches for growth and development due to favourable climatic condition which might have encouraged cell division and cell expansion and led to vigorous vegetative growth. Crop under delayed sown condition experience shorter days and lower temperatures from sowing to emergence and higher temperature during the later period of growth might be decreased vegetative growth span of crop consequently resulted in poor number of branching per plant and nodes up to primary spike. These results are analogous to those reported by DOA (1995), Raghvaiah and Sudhakara (2000), Sree and Reddy (2003), Patel et al., (2005) and Srivastava and Chandra (2010).

Seed yield per primary spike was significantly affected due to different dates of sowing (Table 1.1). The data revealed that crop sown on $15^{\text {th }}$ September recorded the maximum seed yield per primary spike and was statistically at par with $30^{\text {th }}$ September sowing but these both the early sowings viz., $15^{\text {th }}$ September and $30^{\text {th }}$ September recorded significantly superior seed yield per primary spike than late sowing i.e. $15^{\text {th }}$ October. The seed yield per plant was significantly affected by different sowing dates are presented in Table 1.2. Each delay in sowing from $15^{\text {th }}$ September to $15^{\text {th }}$ October reduced seed yield significantly. Significantly the maximum (158.83, 151.30 and $155.06 \mathrm{~g})$ as well as minimum (116.51, 111.13 and $113.82 \mathrm{~g}$ ) seed yield per plant were observed when crop sown on $15^{\text {th }}$ September and $15^{\text {th }}$ October during the year 2011-12, 2012-13 well as in pooled data, respectively. Both the early sowings i.e. $15^{\text {th }}$ September and $30^{\text {th }}$ September were at par and recorded remarkably higher seed yield per primary spike (Table 1.1) than late sowing i.e. $15^{\text {th }}$ October. Whereas, seed yield per plant (Table 1.2) reduced significantly with each delay in sowing from $15^{\text {th }}$ September to $15^{\text {th }}$ October. Respective increase in seed yield per primary spikes were 7.32 and $17.98,5.47$ and 16.15 as well as 6.41 and 17.10 during 2011-12, 201213 and in pooled data due to early sowings viz., $15^{\text {th }}$ and $30^{\text {th }}$ September than late sowing i.e. $15^{\text {th }}$ October. Reduction in seed yield per plant was due to late sowings viz., $30^{\text {th }}$ September and $15^{\text {th }}$ October were 9.87 and 36.23 per cent as compared to early sowing i.e. $15^{\text {th }}$ September. Better vegetative growth in term of plant height and number of branches per plant under early sowing might have responsible for increased in yield attributes which improved seed yield per primary spike and per plant. On the contrary, less time for vegetative growth under delayed sowing might be responsible for poor vegetative growth. Moreover, poor synchronization of flowering or capsules development with lowers temperature which might have affected fertilization (Nagabhushanam and Raghavaiah 2005). The results are complete agreement with those of Baby Akula and Reddy (1998), Sesha et al., (2008) and Srivastava and Chandra (2010).

An appraisal of data (Table 1.2) indicated that 100 -seed weight did not differ significantly due to various dates of sowing during 2011$12,2012-13$ and also in pooled data, respectively. However, delay in sowing reduced 100-seed weight slightly. Similar findings were reported by Chauhan and Yakadri (2004).

Oil yield reduced significantly with each delay in sowing from $15^{\text {th }}$ September to $15^{\text {th }}$ October (Table 1.2). The significantly maximum oil yield of 1114, 1015 and 1065 $\mathrm{kg} \mathrm{ha}^{-1}$ was recorded under $15^{\text {th }}$ September sowing during 2011-12, 2012-13 and in 
pooled data also. But it was the significantly lowest when crop was sown on $15^{\text {th }}$ October. However, oil yield increased remarkably with each successive early in sowing from $15^{\text {th }}$ October to $15^{\text {th }}$ September (Table 1.2). The magnitude of increase in oil yield was to the tune of 13.0 and 40.0,14.0 and 41.0 as well as 14.0 and 41.0 per cent with $15^{\text {th }}$ September sown crop over late sown i.e. $30^{\text {th }}$ September and $15^{\text {th }}$ October crops during 2011-12, 201213 as well as in pooled data, respectively. The oil yield is dependent on oil content in seed and seed yield. Therefore, the higher seed yield was responsible for higher oil yield under early sown crop. Reduction, in oil yield with delayed sowing in rabi season was also reported by Chauhan et al., (2005) and Sesha et al., (2008).

\section{Effect of crop geometry}

Examination of data given in Table 1.1 indicated that varying crop geometry exhibited significant influence on plant population at 30 DAS and at harvest. Significantly the maximum plant population was observed at 30 DAS under crop geometry of $90 \mathrm{~cm} \mathrm{x} 60 \mathrm{~cm}$ whereas, it was the significantly lowest under the wider spacing of $150 \mathrm{~cm} \times 60 \mathrm{~cm}$ during both the years and in pooled data also.

Number of branches per plant in general increased with increase in spacing between two rows from $90 \mathrm{~cm}$ to $150 \mathrm{~cm}$ but significant increase was observed up to 120 $\mathrm{cm}$ row spacing (Table 1.1). The maximum number of branches per plant viz., 7.78, 7.33 and 7.56 were recorded under crop geometry of $150 \mathrm{~cm}$ x $60 \mathrm{~cm}$ during 2011-12, 2012-13 and in pooled data, respectively and was at par with geometry of $120 \mathrm{~cm} \times 60 \mathrm{~cm}$. Both the wider crop geometry was significantly superior to narrow geometry of $90 \mathrm{~cm} \mathrm{x} 60$ $\mathrm{cm}$. The significant effect of crop geometry was found on number of branches per plant
(Table 1.1). Crop sown under wider crop geometry of $150 \mathrm{~cm}$ x $60 \mathrm{~cm}$ and $120 \mathrm{~cm}$ x 60 $\mathrm{cm}$ were at par and recorded remarkably higher number of branches per plant than with crop geometry of $90 \mathrm{~cm}$ x $60 \mathrm{~cm}$. The per cent increase in number of branches per plant due to wider crop geometry of $150 \mathrm{~cm} \mathrm{x} 60 \mathrm{~cm}$ were 3.87 and 40.69 in 2011-12, 0.83 and 40.15 during $2012-13$ as well as 2.44 and 40.52 in pooled data, respectively over closer crop geometry i.e. $120 \mathrm{~cm}$ x $60 \mathrm{~cm}$ and $90 \mathrm{~cm}$ x $60 \mathrm{~cm}$. Wider crop geometry provided more space around each plant resulting in more metabolic activities through better utilization of light, space, water and nutrients which might be turned in better vegetative growth in term of number of branches per plant. Dense population under closer crop geometry reduced number of branches per plant might be due to less availability of space for each plant which increased competition among the plants for available resources. These results corroborate with the findings of Lakshmamma et al., (2003), Singh (2003) and Venugopal et al., (2007).

Crop sown at geometry of $150 \mathrm{~cm} \times 60 \mathrm{~cm}$ and $120 \mathrm{~cm} \times 60 \mathrm{~cm}$ were at par and noted seed yield per primary spike of 53.87, 50.49 and $52.18 \mathrm{~g}$ as well as 52.01, 49.59 and 50.80 $\mathrm{g}$ during 2011-12, 2012-13 and in pooled data, respectively but these both the geometry were significantly higher than inter and intra row spacing of $90 \mathrm{~cm} \times 60 \mathrm{~cm}$. Reduction in crop geometry each from $150 \mathrm{~cm}$ x $60 \mathrm{~cm}$ to $90 \mathrm{~cm} \times 60 \mathrm{~cm}$ reduced seed yield per plant (Table 1.2) significantly. Crop sown at 150 $\mathrm{cm} \times 60 \mathrm{~cm}$ produced the significantly maximum seed yield per plant of 175.25, 169.15 and $172.20 \mathrm{~g}$ during 2011-12, 2012-13 and in pooled data, respectively. However, it was the significantly lowest under crop geometry of $90 \mathrm{~cm} \times 60 \mathrm{~cm}$. The seed yield per primary spike (Table 1.1) and seed yield per plant (Table 1.2) were increased significantly with increase in inter row 
spacing up to $120 \mathrm{~cm}$. The increase in seed yield per primary spike and seed yield per plant with crop geometry of $150 \mathrm{~cm}$ x $60 \mathrm{~cm}$ were to the tune of 2.72 and 7.10 and as well as 25.17 and 71.79 per cent on pooled data basis over crop geometry viz., $120 \mathrm{~cm} \mathrm{x} 60$ $\mathrm{cm}$ and $90 \mathrm{~cm} \times 60 \mathrm{~cm}$, respectively. This was due to reflection of yield attributing characters usually achieved well under optimum availability of space, where competition within the crop plant was minimum. On the other hand, closer crop geometry might be increased competition within the crop plant which resulted in poor growth that decreased the seed yield per primary spike and seed yield per plant. The findings are in conformity with those reported by Singh (2003) and Venugopal et al., (2007).

The data showed in Table 1.2 indicated that the differences in 100-seed weight did not reach the level of significance due to varying crop geometry during 2011-12, 2012-13 and in pooled data also, respectively. Though, the reduction in crop geometry causes negative effect on 100-seed weight. Non significant effect of crop geometry on 100- seed weight during both the years and in pooled data was recorded (Table 1.2). This might be due to 100-seed weight was a variety-specific attribute which was profoundly affected by genetic parameters, but its quantity was determined by the conditions at maturity period, so that these conditions could not change 100-seed weight (Jalilian et al., 2005). There results were in accordance with the reported by Rana et al., (2006) and Patel et $a l .$, (2009).

Data given in Table 1.2 indicated that varying crop geometry exhibited significant response on oil yield. When crop was sown under geometry of $150 \mathrm{~cm} \mathrm{x} 60 \mathrm{~cm}$ produced the maximum oil yield and was at par with 120 $\mathrm{cm} \times 60 \mathrm{~cm}$ but these both the crop geometry were significantly superior than $90 \mathrm{~cm}$ x 60 $\mathrm{cm}$ during the period of investigation and in pooled data also. However, the significantly minimum oil yield of 907,820 and $860 \mathrm{~kg}$ ha ${ }^{1}$ was obtained under crop geometry of $90 \mathrm{~cm}$ x $60 \mathrm{~cm}$ during 2011-12, 2012-13 and in pooled data, respectively. However, oil yield (Table 1.2) increased with increasing in crop geometry from $90 \mathrm{~cm} \times 60 \mathrm{~cm}$ to $150 \mathrm{~cm}$ x 60 $\mathrm{cm}$ but significant increase was found up to120 $\mathrm{cm}$ x $60 \mathrm{~cm}$. Respective per cent increase in oil yield with crop geometry of $150 \mathrm{~cm} \times 60 \mathrm{~cm}$ were to the tune of 1.0 and $10.0,2.0$ and 11.0 as well as 2.0 and 11.0 during 2011-12, 2012-13 as well as in pooled data also over crop geometry of $120 \mathrm{~cm}$ x 60 $\mathrm{cm}$ and $90 \mathrm{~cm} \times 60 \mathrm{~cm}$. The oil yield is dependent on oil content in seed and seed yield. Higher seed yield at crop geometry of $150 \mathrm{~cm} \times 60 \mathrm{~cm}$ responsible for higher oil yield. The findings are in accordance with the results reported by Thadoda (1993), Vala et al., (2000) and Patel et al., (2009).

\section{Effect of levels of nitrogen}

The effect of varying levels of nitrogen on plant population at $30 \mathrm{DAS}$ and at harvest were non-significant during 2011-12, 2012-13 and in pooled data also.

Data showed in Table 1.2 revealed that the differences in number of branches per plant were increased significantly with increase in nitrogen levels. Crop fertilized with $120 \mathrm{~kg} \mathrm{~N}$ $\mathrm{ha}^{-1}$ produced the significantly higher number of branches per plant during the course of investigation and in pooled data also than with $80 \mathrm{~kg} \mathrm{~N}^{-1}$. Marked effect of nitrogen on number of branches per plant was recorded (Table 1.1). Significantly the more number of branches was noted with the application of $120 \mathrm{~kg} \mathrm{~N} \mathrm{ha}^{-1}$ which was 28.50, 30.72 and 29.49 per cent higher during 2011-12, 201213 and in pooled data, respectively than application of $80 \mathrm{~kg} \mathrm{~N} \mathrm{ha}^{-1}$. Thus, increasing 
trend in number of branches per plant might be due to the reason that nitrogen hastens the metabolic activities in the plant body by synthesizing the tryptophan, a precursor, for the auxins, which in turn increased number of branches per plant. But under limited availability of nitrogen reduce cell division and elongation which ultimately reduced number of branches per plant. The results obtained in present study are in close agreement with those reported by Patel et al., (2005) and Rana et al., (2006).

An appraisal of data exhibited in Table 1.1 indicated that an application of $120 \mathrm{~kg} \mathrm{~N} \mathrm{ha}^{-1}$ recorded significantly higher seed yield per primary spike of $53.41,50.27$ and $51.84 \mathrm{~g}$ during 2011-12, 2012-13 and in pooled data, respectively than that of with $80 \mathrm{~kg} \mathrm{~N} \mathrm{ha}^{-1}$. The Increase in nitrogen levels from 80 to 120 $\mathrm{kg} \mathrm{ha}{ }^{-1}$ increased seed yield per plant significantly. The seed yield per plant of 143.59, 137.04 and $140.31 \mathrm{~g}$ recorded with application of $120 \mathrm{~kg} \mathrm{~N} \mathrm{ha}{ }^{-1}$ which was significantly higher than that of with $80 \mathrm{~kg} \mathrm{~N}$ $\mathrm{ha}^{-1}$ during 2011-12, 2012-13 and in pooled data, respectively. The increase in level of nitrogen from 80 to $120 \mathrm{~kg} \mathrm{ha}^{-1}$ increased seed yield per primary spike (Table 1.1) and seed yield per plant (Table 1.2) significantly. As compared to $80 \mathrm{~kg} \mathrm{~N} \mathrm{ha}{ }^{-1}$, the per cent increase in seed yield per primary spike and per plant with $120 \mathrm{~kg} \mathrm{~N}^{-1}$ were 5.35 and 5.34 in 2011-12, 4.95 and 5.63 in 2012-13 as well as 5.15 and 5.47 in pooled data, respectively. This might be due to higher supply of nitrogen sustained the uptake of nitrogen at later crop growth stages which improve vegetative and reproductive growth. Inadequate availability of nitrogen might have produced poor vegetative growth as well as reproductive growth which finally led to less seed yield per primary spike and plant. The results are in complete agreement with those of Patel et al., (2005) and Venugopal et al., (2007).
Effect of varying levels of nitrogen on 100seed weight (Table 1.2) was not reach the level of significant during both the years as well as in pooled data. But increase in nitrogen levels showed it beneficial effect on 100 -seed weight. Increase the levels of nitrogen from 80 to $120 \mathrm{~kg} \mathrm{ha}^{-1}$ increased oil yield significantly. The oil yield of 1029, 934 and $981 \mathrm{~kg} \mathrm{ha}^{-1}$ was produced by $120 \mathrm{~kg} \mathrm{~N}$ $\mathrm{ha}^{-1}$ which was significantly higher than the application of $80 \mathrm{~kg} \mathrm{~N}^{-1}$ during 2011-12, 2012-13 and in pooled data, respectively. Unlike these, oil yield was significantly higher with $120 \mathrm{~kg} \mathrm{~N}^{-1}$ than $80 \mathrm{~kg} \mathrm{~N} \mathrm{ha}^{-1}$. The magnitude of increase in oil yield with application of $120 \mathrm{~kg} \mathrm{~N}^{-1}$ was 14.20 per cent than $80 \mathrm{~kg} \mathrm{~N} \mathrm{ha}^{-1}$. Oil yield is dependent on oil content in seed and seed yield. Increase in seed yield with increase in nitrogen levels might be increased the oil yield. The results obtained in present study are in close agreement with those reported by Thadoda (1993), Sree and Reddy (2003), Kathmale et al., (2008) and Patel et al., (2010).

\section{Significant interaction effects}

The data presented in Table 1.1.1 indicated that the significant interaction effect was observed due to dates of sowing and crop geometry. The significantly highest number of branches per plant of 9.81, 9.04 and 9.42 were recorded when crop sown on $15^{\text {th }}$ September with crop geometry of $150 \mathrm{~cm} \times$ $60 \mathrm{~cm}\left(\mathrm{D}_{1} \mathrm{G}_{1}\right)$ during 2011-12, 2012-13 and in pooled data, respectively. Each delay in sowing from $15^{\text {th }}$ September to $15^{\text {th }}$ October reduced number of branches per plant significantly in wider spacing i.e. $150 \mathrm{~cm} \times$ $60 \mathrm{~cm}$. Whereas, under closer spacing viz., 90 $\mathrm{cm} \times 60 \mathrm{~cm}$ both the late sowings remain at par and recorded significantly lower number of branches per plant than early sowing i.e. $15^{\text {th }}$ September. Under crop geometry of 120 $\mathrm{cm} \times 60 \mathrm{~cm}$ differences between both the early sowings were at par but significantly higher than late sowing. 
Table.1 Plant population of rabi castor at 30 DAS, number of branches per plant and seed yield per primary spike (g) as influenced by varying crop geometry and dates of sowing with levels of nitrogen

\begin{tabular}{|c|c|c|c|c|c|c|c|c|c|c|}
\hline & \multirow[t]{2}{*}{ Treatments } & \multicolumn{3}{|c|}{$\begin{array}{l}\text { Plant population per hectare at } 30 \\
\text { DAS }\end{array}$} & \multicolumn{3}{|c|}{ Number of branches per plant } & \multicolumn{3}{|c|}{ Seed yield per primary spike (g) } \\
\hline & & 2011-12 & 2012-13 & Pooled & 2011-12 & 2012-13 & Pooled & 2011-12 & 2012-13 & Pooled \\
\hline \multicolumn{11}{|c|}{ Dates of sowing (D) } \\
\hline$\left(\mathbf{D}_{1}\right)$ & $15^{\text {th }}$ September & 14423 & 14411 & 14417 & 8.00 & 7.52 & 7.76 & 56.18 & 52.42 & 54.30 \\
\hline$\left(\mathbf{D}_{2}\right)$ & $30^{\text {th }}$ September & 14338 & 14226 & 14282 & 7.13 & 6.94 & 7.04 & 52.35 & 49.70 & 51.03 \\
\hline \multirow[t]{4}{*}{$\left(\mathbf{D}_{3}\right)$} & $15^{\text {th }}$ October & 14323 & 14178 & 14250 & 5.67 & 5.37 & 5.52 & 47.62 & 45.13 & 46.37 \\
\hline & S.Em. \pm & 206 & 231 & 201 & 0.15 & 0.15 & 0.15 & 1.15 & 1.17 & 1.16 \\
\hline & C.D. at $5 \%$ & NS & NS & NS & 0.53 & 0.53 & 0.53 & 3.98 & 4.02 & 3.99 \\
\hline & C.V. $(\%)$ & 7.02 & 8.10 & 7.00 & 10.78 & 11.37 & 11.06 & 10.85 & 11.63 & 11.20 \\
\hline \multicolumn{11}{|c|}{ Crop geometry (G) } \\
\hline$\left(G_{1}\right)$ & $150 \mathrm{~cm} \mathrm{X} 60 \mathrm{~cm}$ & 10988 & 10862 & 10925 & 7.78 & 7.33 & 7.56 & 53.87 & 50.49 & 52.18 \\
\hline$\left(\mathbf{G}_{2}\right)$ & $120 \mathrm{~cm} \mathrm{X} 60 \mathrm{~cm}$ & 13697 & 13550 & 13623 & 7.49 & 7.27 & 7.38 & 52.01 & 49.59 & 50.80 \\
\hline \multirow[t]{4}{*}{$\left(\mathbf{G}_{\mathbf{3}}\right)$} & $90 \mathrm{~cm} \mathrm{X} \mathrm{60cm}$ & 18399 & 18403 & 18401 & 5.53 & 5.23 & 5.38 & 50.27 & 47.17 & 48.72 \\
\hline & S.Em. \pm & 238 & 317 & 265 & 0.14 & 0.13 & 0.13 & 0.95 & 0.89 & 0.92 \\
\hline & C.D. at $5 \%$ & 704 & 938 & 786 & 0.40 & 0.37 & 0.39 & 2.81 & 2.64 & 2.72 \\
\hline & C.V. $(\%)$ & 8.10 & 10.87 & 9.08 & 9.54 & 9.30 & 9.42 & 8.93 & 8.89 & 8.89 \\
\hline \multicolumn{11}{|c|}{ Nitrogen levels $(\mathbf{N})$} \\
\hline$\left(\mathbf{N}_{1}\right)$ & $80 \mathrm{~kg} \mathrm{ha}^{-1}$ & 14345 & 14262 & 14303 & 6.07 & 5.73 & 5.90 & 50.70 & 47.90 & 49.30 \\
\hline \multirow[t]{4}{*}{$\left(\mathbf{N}_{2}\right)$} & $120 \mathrm{~kg} \mathrm{ha}^{-1}$ & 14378 & 14282 & 14330 & 7.80 & 7.49 & 7.64 & 53.41 & 50.27 & 51.84 \\
\hline & S.Em. \pm & 223 & 215 & 214 & 0.12 & 0.11 & 0.12 & 0.83 & 0.81 & 0.82 \\
\hline & C.D. at $5 \%$ & NS & NS & NS & 0.35 & 0.33 & 0.34 & 2.41 & 2.34 & 2.37 \\
\hline & C.V. (\%) & 9.30 & 9.06 & 8.95 & 10.37 & 10.32 & 10.34 & 9.60 & 9.87 & 9.71 \\
\hline \multicolumn{2}{|c|}{ Sig. Interaction } & - & - & - & $\mathrm{DxG}$ & DxG & DxG & - & - & - \\
\hline
\end{tabular}


Table.2 Seed yield per plant (g), 100-seed weight (g) and oil yield (kg ha-1) as influenced by varying crop geometry and dates of sowing with levels of nitrogen on rabi castor

\begin{tabular}{|c|c|c|c|c|c|c|c|c|c|c|}
\hline & \multirow{2}{*}{ Treatments } & \multicolumn{3}{|c|}{ Seed yield per plant (g) } & \multicolumn{3}{|c|}{ 100-seed weight (g) } & \multicolumn{3}{|c|}{ Oil yield (kg ha $\left.{ }^{-1}\right)$} \\
\hline & & 2011-12 & 2012-13 & Pooled & 2011-12 & 2012-13 & Pooled & 2011-12 & 2012-13 & Pooled \\
\hline \multicolumn{11}{|c|}{ Dates of sowing (D) } \\
\hline$\left(D_{1}\right)$ & $15^{\text {th }}$ September & 158.83 & 151.30 & 155.06 & 29.95 & 29.84 & 29.90 & 1114 & 1015 & 1065 \\
\hline$\left(\mathbf{D}_{2}\right)$ & $30^{\text {th }}$ September & 144.51 & 137.75 & 141.13 & 28.14 & 28.03 & 28.09 & 985 & 889 & 937 \\
\hline \multirow[t]{4}{*}{$\left(\mathbf{D}_{3}\right)$} & $15^{\text {th }}$ October & 116.51 & 111.13 & 113.82 & 26.78 & 26.46 & 26.62 & 797 & 719 & 758 \\
\hline & S.Em. \pm & 3.01 & 3.35 & 3.18 & 0.72 & 0.76 & 0.74 & 31 & 33 & 32 \\
\hline & C.D. at $5 \%$ & 10.38 & 11.57 & 10.97 & NS & NS & NS & 106 & 115 & 111 \\
\hline & C.V. $(\%)$ & 10.53 & 12.32 & 11.40 & 12.45 & 13.25 & 12.79 & 15.63 & 18.66 & 17.03 \\
\hline \multicolumn{11}{|c|}{ Crop geometry $(G)$} \\
\hline$\left(G_{1}\right)$ & $150 \mathrm{~cm} \mathrm{X} \mathrm{60cm}$ & 175.25 & 169.15 & 172.20 & 28.61 & 28.44 & 28.53 & 1001 & 912 & 957 \\
\hline$\left(G_{2}\right)$ & $120 \mathrm{~cm} \mathrm{X} \mathrm{60cm}$ & 140.96 & 134.19 & 137.57 & 28.44 & 28.22 & 28.33 & 989 & 891 & 940 \\
\hline \multirow[t]{4}{*}{$\left(G_{3}\right)$} & $90 \mathrm{~cm}$ X $60 \mathrm{~cm}$ & 103.64 & 96.84 & 100.24 & 27.82 & 27.67 & 27.75 & 907 & 820 & 863 \\
\hline & S.Em. \pm & 2.46 & 2.48 & 2.45 & 0.53 & 0.53 & 0.53 & 26 & 25 & 26 \\
\hline & C.D. at $5 \%$ & 7.27 & 7.35 & 7.27 & NS & NS & NS & 78 & 76 & 77 \\
\hline & C.V. $(\%)$ & 8.60 & 9.12 & 8.80 & 9.23 & 9.18 & 9.18 & 13.42 & 14.28 & 13.78 \\
\hline \multicolumn{11}{|c|}{ Nitrogen levels $(\mathbf{N})$} \\
\hline$\left(\mathrm{N}_{1}\right)$ & $80 \mathrm{~kg} \mathrm{ha}^{-1}$ & 136.31 & 129.74 & 133.03 & 27.84 & 27.58 & 27.71 & 902 & 815 & 859 \\
\hline \multirow[t]{4}{*}{$\left(\mathbf{N}_{2}\right)$} & $120 \mathrm{~kg} \mathrm{ha}^{-1}$ & 143.59 & 137.04 & 140.31 & 28.74 & 28.65 & 28.69 & 1029 & 934 & 981 \\
\hline & S.Em. \pm & 2.29 & 2.32 & 2.30 & 0.43 & 0.44 & 0.43 & 26 & 23 & 24 \\
\hline & C.D. at $5 \%$ & 6.62 & 6.73 & 6.65 & $\mathrm{NS}$ & NS & NS & 74 & 67 & 70 \\
\hline & C.V. $(\%)$ & 9.82 & 10.46 & 10.09 & 9.08 & 9.45 & 9.22 & 15.90 & 15.93 & 15.85 \\
\hline \multicolumn{2}{|c|}{ Sig. Interaction } & $\mathrm{D} \times \mathrm{G}$ & $\mathrm{D} \times \mathrm{G}$ & $\mathrm{D} \times \mathrm{G}$ & - & - & - & & & \\
\hline
\end{tabular}


Table.3 Interaction effect of crop geometry and date of sowing on number of branches plant per plant during 2011-12, 2012-13 and in pooled results

\begin{tabular}{|c|c|c|c|c|c|c|c|c|c|}
\hline \multirow{2}{*}{$\begin{array}{l}\text { Dates of sowing } \\
\text { /Geometry }\end{array}$} & \multicolumn{3}{|c|}{ 2011-12 } & \multicolumn{3}{|c|}{ 2012-13 } & \multicolumn{3}{|c|}{ Pooled } \\
\hline & $\mathbf{G}_{1}$ & $\mathbf{G}_{2}$ & $\mathbf{G}_{3}$ & $\mathbf{G}_{1}$ & $\mathbf{G}_{2}$ & $\mathbf{G}_{3}$ & $\mathbf{G}_{1}$ & $\mathbf{G}_{2}$ & $\mathbf{G}_{3}$ \\
\hline $\mathrm{D}_{1}$ & 9.81 & 8.10 & 6.10 & 9.04 & 7.93 & 5.60 & 9.42 & 8.01 & 5.85 \\
\hline $\mathrm{D}_{2}$ & 8.35 & 7.83 & 5.23 & 7.96 & 7.73 & 5.14 & 8.15 & 7.78 & 5.18 \\
\hline $\mathrm{D}_{3}$ & 5.27 & 6.54 & 5.20 & 5.00 & 6.15 & 4.95 & 5.14 & 6.35 & 5.08 \\
\hline S.Em. \pm & \multicolumn{3}{|c|}{0.23} & \multicolumn{3}{|c|}{0.22} & \multicolumn{3}{|c|}{0.23} \\
\hline C.D. at $5 \%$ & \multicolumn{3}{|c|}{0.69} & \multicolumn{3}{|c|}{0.64} & \multicolumn{3}{|c|}{0.67} \\
\hline C.V. (\%) & \multicolumn{3}{|c|}{9.54} & \multicolumn{3}{|c|}{9.30} & \multicolumn{3}{|c|}{9.42} \\
\hline
\end{tabular}

Table.4 Interaction effect of crop geometry and date of sowing on seed yield per plant (g) during 2011-12, 2012-13 and in pooled results

\begin{tabular}{|c|c|c|c|c|c|c|c|c|c|}
\hline \multirow{2}{*}{$\begin{array}{c}\text { Date of } \\
\text { sowing / } \\
\text { Geometry }\end{array}$} & \multicolumn{3}{|c|}{ 2011-12 } & \multicolumn{3}{|c|}{ 2012-13 } & \multicolumn{3}{|c|}{ Pooled } \\
\hline & $\mathbf{G}_{\mathbf{1}}$ & $\mathbf{G}_{2}$ & $\mathbf{G}_{3}$ & $\mathbf{G}_{1}$ & $\mathbf{G}_{2}$ & $\mathbf{G}_{3}$ & $\mathbf{G}_{\mathbf{1}}$ & $\mathbf{G}_{2}$ & $\mathbf{G}_{3}$ \\
\hline$D_{1}$ & 201.17 & 161.11 & 114.20 & 193.64 & 153.35 & 106.90 & 197.41 & 157.23 & 110.55 \\
\hline $\mathrm{D}_{2}$ & 181.97 & 147.01 & 104.56 & 175.37 & 139.05 & 98.83 & 178.67 & 143.03 & 101.69 \\
\hline $\mathrm{D}_{3}$ & 142.61 & 114.77 & 92.15 & 138.43 & 110.16 & 84.80 & 140.52 & 112.46 & 88.48 \\
\hline S.Em. \pm & \multicolumn{3}{|c|}{4.25} & \multicolumn{3}{|c|}{4.30} & \multicolumn{3}{|c|}{4.25} \\
\hline C.D. at $5 \%$ & \multicolumn{3}{|c|}{12.60} & \multicolumn{3}{|c|}{12.74} & \multicolumn{3}{|c|}{12.59} \\
\hline C.V. (\%) & \multicolumn{3}{|c|}{8.60} & \multicolumn{3}{|c|}{9.12} & \multicolumn{3}{|c|}{8.80} \\
\hline
\end{tabular}

Significant interaction effect was recorded between dates of sowing and crop geometry during 2011-12, 2012-13 and in pooled data also (Table 1.1.2). The significantly maximum seed yield per plant was recorded when crop sown on $15^{\text {th }}$ September with geometry of $150 \mathrm{~cm} \quad \mathrm{x} 60 \mathrm{~cm} \quad\left(\mathrm{D}_{1} \mathrm{G}_{1}\right)$. Significantly the lowest seed yield per plant was recorded when crop was sown $15^{\text {th }}$ October at $90 \mathrm{~cm}$ x $60 \mathrm{~cm}$ crop geometry $\left(\mathrm{D}_{3} \mathrm{G}_{3}\right)$ during both the years as well as in pooled data except in 2011-12. Each delay in sowing with reduced inter row spacing from $150 \mathrm{~cm}$ to $90 \mathrm{~cm}$ decreased seed yield per plant significantly during course of investigation and in pooled data except during 2011-12 where difference between late sowings i.e. $30^{\text {th }}$ September or $15^{\text {th }}$ October as well as crop geometry of $90 \mathrm{~cm}$ x $60 \mathrm{~cm}$ were non significant.

\section{References}

Akula Baby and Reddy Bapi. 1998. Effect of dates of sowing on yield castor cultivars. J. Oilseeds Res., 15(2): 375-376.

Chauhan Sreedhar and Yakadri, M. 2004. Sowing date and genotype effects on performance of rabi castor (Ricinus communis L.) in alfisols. J. Res. ANGRAU, 32(2): 90-92.

Chavan, M., Pujari, B.T. and Lokesha, R. 2005. Available nitrogen content in soil and its uptake by castor as influenced by green manures and nitrogen levels on castor yield. Karnataka J. Agri. Sci., 18(4): 1078-1080.

DOA. 1995. Effect on dates of sowing on the yield of actor cultivars (Palem). Annual Progress Report of All India Co-ordinated Research Project on Oilseeds, Hyderabad, 
pp. 68-69.

Kathmale, D.K., Danawale, N.J. and Deshpande, A.N. 2008. Effect of spatial configurations and fertilizer levels on the performance of castor under dryland conditions. Indian J. Dry land Agri. Res. Develop., 23(2): 80-85.

Lakshmamma, P., Lakshmi Prayaga and Reddy, A. V. (2003). Yield variation due to nipping of branches in combination with population manipulations in castor (Ricinus communis L.). Indian Journal of Plant Physiology, 8 (1): 70-73.

Nagabhushanam, U. and Raghavaiah, C.V. 2005. Seeding date and irrigation effects on the productivity and oil quality of postmonsoon grown castor (Ricinus communis L.) in Alfisols. J. Oilseeds Res., 22(1): 206-208.

Patel, R.M., Patel, M.M. and Patel, G.N. 2010. Effect of preceding kharif crops, spacing and nitrogen levels on yield and nutrients uptake by rabi castor. Gujarat Agri. Univ. Res. J., 3(1): 15-17.

Patel, R.M., Patel, M.M. and Patel, G.N. 2009. Effect of spacing and nitrogen levels on rabi castor (Ricinus communis L.) grown under different cropping sequences in North Gujarat agro-climatic conditions. J. Oilseeds Res., 26(2): 123125.

Raghvaiah, C.V. and Sudhakara Babu, S.N. 2000. Effect of seedling date, female: male row proportion and nitrogen on certified seed production on certified seed production of GCH 4 (VP 1 x 48 1) castor hybrid. J. Oilseeds Res., 7(1): 100-106.

Rana, D.S., Giri, G. and Pachauri, D.K. 2006. Evaluation of castor (Ricinus communis L.) genotypes for productivity, economics, litter fall and changes in soil properties under different levels of interrow spacing and nitrogen. Indian $J$. Agronomy, 51(4): 318-322.

Sesha, P., Saila Sree, B., Bhaskar Reddy and D., Swapna Sree. 2008. Performance of castor cultivars at different dates of sowing in rice fallows. J. Agri. Res., 42(2): 125-128.

Sree, P.S. and Reddy, B.B. 2003. Performance of castor cultivars at different dates of sowing. Annals of Agri. Res., 24(3): 546-551.

Srivastava, S.K. and Chandra, D.R. 2010. Effect of sowing dates on growth and productivity of castor (Ricinus communis L.) genotypes in central agro-climatic zone of Uttar Pradesh. J. Oilseeds Res, 27(2): 190-191.

Vala, G.M., Khanpara, V.D., Kaneria, B.B. and Mathukia, R.K. 2000. Performance of castor (Ricinus communis L.) genotypes under various sowing times and row spacing in summer season. Gujarat Agric. Univ. Res. J., 26(1): 12-15.

Venugopal, C., Reddy, G. K. and Reddy, G.P. 2007. Growth attributes, nitrogen uptake and seed yield of rainfed castor as influenced by plant geometry and nitrogen levels. J. Res. ANGRAU, 35(3): 78-81.

\section{How to cite this article:}

Mukesh Kumar Man, A.U. Amin, K.M. Choudhary and Annu Devi Gora. 2017. Response of Castor (Ricinus communis L.) To Varying Weather Variables and Crop Geometry with Levels of Nitrogen under Rabi Season. Int.J.Curr.Microbiol.App.Sci. 6(5): 2409-2418. doi: https://doi.org/10.20546/ijcmas.2017.605.269 